\title{
Implementation Of Progressive Tax Policy For Two And Four Wheel Vehicles In Indonesia
}

\author{
Muljadi Djaja, SE.Ak, SH, CPA, CA, BKP \\ Institut STIAMI \\ DOI: 10.29322/IJSRP.11.07.2021.p11581 \\ http://dx.doi.org/10.29322/IJSRP.11.07.2021.p11581
}

\begin{abstract}
Public policy has two main functions, namely budgeting and regulation. The same is the case with the Progressive Tax Policy for Two-Wheeled and Four-Wheeled Vehicles which is regulated in Provincial Regulation X Number 1 of 2011 which came into effect in 2012. This researcher uses descriptive qualitative research methods. Data collection procedures used by interview, observation, documentation. Data analysis was performed by reducing data, presenting data and summarizing conclusions. The results of this study indicate that the implementation of the policy to enforce progressive tax on motorized vehicles which includes communication, human resources, executive attitudes, and bureaucracy has been carried out properly by $X$, namely: (1) Communication is carried out externally by publishing progressive taxes to the public or taxpayers. using print media and electronic media. (2) Human resources shall be implemented by preparing personnel for motor vehicle progressive tax service officers in accordance with their respective fields of work and supported by adequate public service facilities and infrastructure. (3) The attitude of the implementer is carried out by Samsat employees by providing good service attitudes to taxpayers who pay progressive tax in accordance with established standard operating procedures, (4) Bureaucracy is implemented by simplifying the bureaucracy of motor vehicle tax payment services by forming a working group, so that it becomes easier for taxpayers to obtain progressive tax services at X.
\end{abstract}

Index Terms- Implementation, Policy, Progressive Tax and TwoWheeled Vehicle Tax and Four Wheels

\section{INTRODUCTION}

$\mathrm{C}$ ty $\mathrm{X}$ is the third largest city in Indonesia which is developing and has a very fast development rate for two-wheeled and four-wheeled vehicles. The development of two-wheeled and four-wheeled vehicles is certainly used by the City Government of $\mathrm{X}$ to collect taxes on the owners or rulers of these two-wheeled and four-wheeled vehicles, in order to increase the source of the Original Regional Income of City X which is very influential to the City Regional Expenditure Budget X. enforcement of the rules, there is no opportunity for consumers to find loopholes to cheat. With the implementation of a progressive tax on two-wheeled and four-wheeled vehicles aimed at reducing the number of vehicles, this policy can increase Motor Vehicle Tax revenue in big cities. By achieving a reduction in the use of two and four-wheeled wheels in big cities, it will also be able to reduce the level of traffic congestion on the highway. In fact, most residents in City X do not fully understand the application of progressive taxes. This raises a little problem when residents pay for the two-wheeled and four-wheeled vehicles they own. They often have to pay more because the number of vehicles registered under their names is more than one.

Even though the vehicle has actually changed hands. This often happens because the owner of the first vehicle has sold twowheeled and four-wheeled vehicles to a second party, but the vehicle is still in the name of the first owner because he has not changed the name. With the fact that one name is on behalf of several motorized vehicles, even though the vehicle has changed hands, they should be subject to a progressive tax on vehicles that are no longer under their control. Ownership of the number of vehicles as the basis for taxation, and the percentage increases for each certain amount each time it increases.

Progressive tax contains the principle of justice, in which people who are getting richer naturally pay higher taxes. Another reason for the government to apply this rule is to cover the shortfall in revenue for Province $\mathrm{X}$ in the future. The new tax regulation is expected to cover the loss of potential local revenue. Imposing taxes apart from being based on local revenue targets, also considers environmental aspects. Progressive tax from the Budgetary (Financial) Function is to enter as much income as possible to the State treasury, in this case, the Regional Original Income. Meanwhile, from the function of Regulation (Regulating) progressive tax is used as a tool to regulate both the community in the economic, social, and political fields with certain objectives, in this case, to reduce the number of motorized vehicles and reduce the level of congestion.

Referring to Article 6 paragraph (2) of Law of the Republic of Indonesia Number 28 of 2009 concerning Regional Taxes and Regional Levies, ownership of motorized vehicles is based on the same name and / or address. However, the Law does not provide an explanation for the "control" referred to in the definition of motor vehicle tax. However, not a few interpreted that what is meant by control is seen from the Proof of Ownership of Motorized Vehicles and Certificate of Vehicle Numbers.

This will not cause a problem if the government can disseminate it well to the community. The role of regional governments in administering governance and development as well as community services in the implementation of regional autonomy will increase, this role enhancement is based on the ability of the regions to optimally manage their own regions, including the management of resources. 


\section{LITERATURE REVIEW}

\section{Definition of Implementation}

Etymologically the concept of implementation from the point of view of cyclical theory, implementation will be treated as an important stage that takes place in the policy process, especially after formal legal discourse, usually in the form of laws, regulations, stipulations, or forms. -Other forms of legal products are considered expired. So in the broadest sense, implementation is often considered as a form of operationalization or implementation of activities that have been determined based on law and become a collective agreement among various stakeholders, actors, organizations (public or private), procedures, and techniques. synergistically driven to work together in order to implement policies in a certain desired direction. According to Sinulingga, L. O. B. (2018) formulated the implementation process as "actions taken by either individual officials or government or private groups directed at achieving the goals outlined in policy decisions. According to Adiputra, M., Karamoy, H., \& Pangerapan, S. (2018) there are six variables that affect implementation performance, namely:

1. Policy Standards and Targets Standard and policy objectives must be clear and measurable, so they can be realized. If standards and policies are blurred, there will be multiple interpretations and it is easy to cause conflicts between implementation agencies.

2. Policy Resources Policy implementation needs support from human resources as well as human resources.

3. Inter-Organizational Communication In implementing the program, support and coordination with other agencies is needed. For that we need coordination and cooperation between agencies for the success of a program.

4. Characteristics of the Executing Agency The implementing agency includes the bureaucratic structure, norms, and patterns of relationships that occur within the bureaucracy, all of which will influence the implementation of a program.

5. Social, Economic, and Political Conditions This variable includes economic and environmental resources that can support the successful implementation of policies. The extent to which interest groups can provide support for policy implementation, the characteristics of the participants, namely supporting or rejecting, what is the nature of public opinion in the environment, and whether the political elite supports policy implementation.

6. Trend of the Implementing Agency The trend of the Implementing Agency includes three things, namely:

a) the response of the implementer to the policy which will be influenced by his willingness to implement the policy,

b) Cognition, namely understanding of policies, and

c) the intensity of the implementor's disposition, namely the value preference possessed by the implemtator.

According to (Dwipurna, MWF, 2015) explaining the meaning of this implementation by saying that understanding what actually happens after a program is declared valid or formulated is the focus of attention to policy implementation, namely events and activities that arise after the promulgation of public policy guidelines public policy which includes both efforts to administer it and to cause real consequences / impacts on society or events.
According to Supriliyani, N. W., \& Yudharta, I. P. D. (2018), the main need for the effectiveness of policy implementation is that those who implement decisions must know what they should do. If policies are to be implemented appropriately, directives and implementation guidelines must not only be accepted but also clear, and if this is not clear the implementers will be confused about what they should do, and in the end they will have their own policies regarding which policy implementation this view is often different from those of their superiors.

\section{Definition of Policy}

The term concept of policy (policy) is often used interchangeably with other terms such as goals, programs, decisions, statutory provisions, proposals and grand drafts. Sudrajat, E. I. (2017), argues that policy should be distinguished from wisdom because wisdom is knowledge of rules that have been determined according to the local situation and conditions by an authorized official. According to Kuswandi, A. (2019) policy is a series of principles, or desired conditions, as a product, policy is seen as a series of conclusions or recommendations, and as a process, policy is seen as a way through which an organization can find out what is happening. he expects from him, namely programs and mechanisms for achieving their products, and as a framework, policy is a process of bargaining and negotiation to formulate issues and methods for their implementation.

According to Pratiwi, F. W. (2016), policy is an action that has a goal by an actor or a number of actors to solve a problem. Furthermore, Pratiwi, F. W. (2016), classifies policies into two: substantive and procedural. 1. Substantive policies, namely what the government must do. 2. Procedural policy, namely who and how the policy is implemented. This means, public policies are policies developed by government agencies and officials.

\section{Definition of Tax}

Progressive Tax Progressive is the percentage of tax that will increase by a certain percentage when the taxable object value also increases, and there is an increase in the percentage of each increase in the value of the tax object in a certain amount. Progressive tax is the greater the percentage if the amount that must be taxed is bigger (Mardiasmi, 2011: 7). The use of this rate allows recipients of higher income to distribute their income to recipients of lower income through tax payments.

\section{General Information Regarding Progressive Taxes on Motor Vehicle Taxes}

\section{Taxpayers}

For example, for the implementation of progressive tax on motor vehicle tax in X, based on Perda Nommor 1 of 2011 concerning Motor Vehicle Tax. Progressive taxpayers of Motor Vehicle Tax are private individuals who own motorized vehicles.

\section{Tax Objects}

Based on Law no. 28 of 2009 concerning Regional Taxes and Regional Levies stipulates that progressive taxes are imposed on ownership of motorized vehicles based on the same name and / or address. Tax from 4 (four) and 4 (four) wheeled vehicles or more. For example, an individual who owns 1 (one) 2 (two) wheeled motorized vehicle, 1 (one) 3 (three) wheeled motor vehicle and 1 (one) 4 (four) wheeled vehicle, are each treated as the first ownership so that not subject to progressive tax. 
3. Reporting In order for taxpayers to avoid progressive taxes on motor vehicle taxes on motor vehicles that have been transferred (for example by way of sales) to other parties. So in practice, the taxpayer can promise the new owner / buyer of the motor vehicle to immediately reverse the name on his behalf. In addition, in practice the taxpayer can report it to the One-Stop One-Stop Administration System, the Provincial Government Tax Service Office where the transferred motor vehicle is registered. This is done 30 (thirty) days after the transfer of the motor vehicle is carried out. The taxpayer submits a statement letter whose form is available at the relevant Samsat. After the statement letter form is filled in completely and correctly, the taxpayer signs it on a stamp of Rp. 6,000.00. In addition, taxpayers must also complete it with a photocopy of their Identity Card and Family Card.

\section{Local tax}

1. The Concept of Local Taxes.

According to Law Number 28 of 2009 concerning Regional Taxes and Retribution, Regional Taxes are contributions that must be paid to the region by an individual or entity without direct reciprocity and can be enforced based on existing laws and regulations, which are used for purposes local government and local development.

2. Types of Local Taxes.

Taxes from regions are divided into two based on Law Number 28 of 2009 concerning Regional Taxes and Regional Levies, namely Provincial taxes and City / Regency taxes. Provincial taxes consist of 5 (five) types of taxes collected, one of which is Motor Vehicle Tax. Meanwhile, for cities / regencies there are 11 (eleven) types of taxes that are collected.

1) Concept of Motor Vehicle Tax. Based on Law Number 28 of 2009 concerning Regional Taxes \& Regional Retributions, Motor Vehicle Tax is a tax on people who own or control a motorized vehicle.

2) Motor Vehicle Tax Objects. Based on the policy of North Sulawesi Province Number 7 of 2011 concerning Regional Taxes, the object of motorized vehicle tax is a person who owns or controls a motorized vehicle.

3) Subjects for Motor Vehicle Tax. Based on North Sulawesi Provincial Policy Number 7 of 2011 concerning Regional Taxes, the subject of motorized vehicle tax is an individual, agency, government, local government, TNI and Polri who own and / or control motorized vehicles.

4) Motor Vehicle Taxpayers. Based on North Sulawesi Provincial Policy Number 7 of 2011 concerning Regional Taxes, Article 5 Motorized Vehicle Taxpayers, namely: (1) the person concerned, namely as the owner in accordance with their ownership rights; (2) a person or body obtaining the power of attorney from the owner of a motor vehicle; and (3) heirs.

5) Basis of Motor Vehicle Tax Imposition. Based on the Regional Policy of North Sulawesi Province Number 7 of 2011 concerning Regional Taxes, the imposition of motor vehicle tax is the product of the Motor Vehicle Sales Value and the Weight which is the level of tolerance for a vehicle.

6) Motor Vehicle Tax Rates. According to Law Number 28 of 2009 concerning Regional Tax \& Retribution, the imposition of tariffs for motorized vehicles is $1 \%$ (one percent) and a maximum of $2 \%$ (two percent) for the control of the first vehicle. Meanwhile, the next control is determined from $2 \%$ (two percent) and a maximum of $10 \%$ (ten percent).

7) Progressive Tax. Progressive tax is a tax whose collection increases the tax rate payable with increasing tax objects. Motor vehicle progressive tax is a tax collected for private vehicles, both two-wheeled and four-wheeled, with the same owner's name and residential address.

\section{Concept of Public Policy Implementation}

Winarno (2014) defines policy implementation as actions taken by the government or private sector, either individually or in groups with the intention of achieving the goals formulated in the policy. According to Van Meter and Van Horn in Winarno (2014) limiting the implementation of policies as actions taken by individuals or groups of government or private that are directed to achieve the goals set in previous policy decisions.

Van Meter and Van Horn also mentioned a model called A Model Of The Policy Implementation Process (in Abdul Wahab 2004), namely: (1) Policy standards and goals that explain the details of the overall policy decision objectives, (2) ) Policy resources in the form of implementation support funds, (3) Communication between organizations and measurement activities are used by executors to determine the objectives to be achieved, (4) Implementation characteristics, meaning that organizational characteristics are crucial factors that will determine the success or failure of a program, (5) Conditions socio-economic and political factors that can influence the outcome of policies and (6) the attitude of implementation in understanding the policies to be established.

\section{RESEARCH METHODOLOGY}

This type of research is qualitative research. The nature of this research is descriptive. According to Sugiono (2006: 11), According to Creswell in Jamaluddin Ahmad (2015: 52), qualitative research is methods to explore and understand the meaning that a number of individuals or groups of people consider to originate from social or humanitarian problems. This qualitative research process involves important efforts, such as asking questions and procedures, collecting specific data from participants, analyzing data inductively from specific themes to general themes, and interpreting the meaning of the data.

Implementation of 4 (Four) Wheeled Motor Vehicle Progressive Tax Policy at the Regional Revenue Service X. This research uses a descriptive type of research, which describes and understands the symptoms that occur in the field in detail regarding the Implementation of the Progressive Tax Policy for 4 (Four) Wheeled Motor Vehicles at the Revenue Service. Region $\mathrm{X}$ Province. 
Data Collection Methods To obtain data from the field, researchers used several data collection methods according to the type of research, while the data collection methods were as follows:

\section{a. Study Libraries}

Literature is all efforts made to gather information relevant to the topic / problem to be / is being researched. This information can be obtained from scientific books, research reports, scientific papers, theses, regulations and written sources.

\section{b. Observation}

According to Nasution (1998: 64) states that observation is the basis of all knowledge. Scientists can only work on data, namely facts about the real world that are obtained through observation. This data is collected, often with the help of very sophisticated tools, so that both very small (protons and electrons) and very distant (space objects) objects can be clearly observed. In making observations, the researcher first looks at the location or place you want to research, namely the One-stop Administration Services Office $\mathrm{X}$ regarding the existence of a Progressive Tax Policy for Motor Vehicle Taxpayers in Increasing Local Original Income.

c. Interview

According to Ester (2002: 316), an interview is defined as a meeting of two people to exchange information and ideas through questions and answers, so that meaning can be constructed in a particular topic.

\section{d. Documentation}

According to Sugiyono (2014: 326) Documentation is a record of events that have passed. Documentation can be in the form of writings, pictures or monumental works of a person. Documentation in the form of writing, for example, diaries, life histories, biographies, regulations, policies. Documentation in the form of images, for example photos, live pictures, sketches and others. Documentation in the form of works, for example works of art, which can be in the form of pictures, sculptures, films, and so on.

\section{RESULTS AND DISCUSSION}

\section{Result}

Implementation of Progressive Taxes on Motor Vehicles in Province $\mathrm{X}$. Based on the results of interviews conducted by researchers, the increase in motor vehicle tax rates (Progressive Rates) began to take effect in Province X. The implementation of this progressive tax rate is based on Law Number 28 of 2009 concerning Regional Taxes and Regional Retribution, whose implementation is based on Provincial Policy X Number 7 of 2011 concerning Regional Taxes. The increase in the vehicle tax rate applies to controls that exceed one unit. The increase in vehicle tax rates applies to 2 (two) to 2 (two) wheeled vehicles and 4 (four) to 4 (four) wheeled vehicles, except for vehicles of the type of Dump Truck, Light Truck and Pick Up. 2. Determination of the Progressive Tax Sequence of Motor Vehicles The determination of the progressive tax rate on motorized vehicles is determined according to the registration time of the vehicle stored in the data bank. As for used vehicles, the order is based on the oldest year of the vehicle or the year when the name of the motor vehicle was changed.

\section{Discussion}

This publication is licensed under Creative Commons Attribution CC BY.

http://dx.doi.org/10.29322/IJSRP.11.07.2021.p11581
Implementation of Progressive Taxes on Motor Vehicles in City X Based on the results of researchers' observations, the implementation of progressive taxes in North Minahasa Regency has used an integrated computerized system where every taxpayer data who owns a vehicle will be recorded in the database. This database is a database or information collection of vehicle owners that is stored systematically so that it can be checked using a computer program to obtain information from the database. The database stores all the information needed about motorized vehicles, including:

1. The number of vehicle ownership in a certain area, be it 2 (two) wheeled vehicles, 4 (four) wheels, 6 (six) wheels and so on.

2. The number of vehicles in arrears (not paying taxes).

3. The number of vehicles that are due for payment.

4. Taxpayers who are subject to progressive rates starting from two wheels (two wheels) and so on.

5. The number of vehicle owners who come to pay each day.

6. New vehicle data.

7. Vehicle data that is mutated, both incoming and outgoing mutations.

8. Data on Transfer of Motor Vehicle Title Fee.

This database is the basis for administration carried out by the One-stop Administration Services Office, so that it can identify each motorized vehicle in terms of vehicle registration and for other purposes. The system has also been filled with coding, namely the vehicle identification code according to the type, type, brand and number of wheels. Based on the database, it can be seen how much the Motor Vehicle Sales Value is and the amount of motor vehicle tax determination. For progressive tax payment rates are determined based on the order of ownership of the taxpayer's vehicle in the database so that the rate of each taxpayer's vehicle that will pay motorized vehicle tax can be seen.

However, it often happens when the taxpayer does not own / control a motorized vehicle but in the database it is still recorded as the name of the taxpayer so that the taxpayer has to pay the tax burden that he does not already have. For this reason, taxpayers can report that the vehicle has been sold so that the order and rates of the vehicles can change. When paying motor vehicle tax, the system will be connected to the database, then the system will follow the existing database and calculate by itself how much the taxpayer must pay. Determination of the Order of Ownership of Motor Vehicles According to the results of interviews with the head of the Agency's Technical Implementation Unit, the increase in motor vehicle tax rates has existed since January 2011, but at that time it only served as an outreach. Vehicle owners are given relief by not paying administrative fees to carry out Transfer of Motorized Vehicle Name Fees and provide facilities for vehicle owners to regulate the order of their vehicles and as a way to increase Motorized Vehicle Name Transfer Fees.

\section{Inhibiting Factors in the Implementation of Progressive Taxes on Motor Vehicles}

1. Barriers for employees in charge of carrying out motorized vehicle identification in the field. When the employee on duty arrives at the vehicle owner's residence but the vehicle owner is not present. As a result, the 
employee on duty takes another route, namely asking the status of the vehicle to the people around the vehicle owner's residence, but not all neighbors or people who are found in the field want to provide information to the officer regarding the taxpayer / owner of the vehicle in question.

2. Facilities and Infrastructure. Because not all vehicle owners can pay vehicle tax during working hours because there are vehicle owners who work at the same hours.

3. Constraints from the One-stop Administration Services Office. When providing services to taxpayers, sometimes there is a wrong determination or wrong input of data so that it can interfere with the operation of the motor vehicle tax collection mechanism which makes taxpayers wait so that the determination data or incorrect data input is corrected.

4. Community Factors as Taxpayers. There is still a lack of understanding of taxpayers on the application of progressive tax rates on motorized vehicles.

\section{The Impact of Progressive Motor Vehicle Taxes}

The implementation of the increase in motor vehicle tax rates has an impact on society and the government. The positive impact on society is the implementation of the increase in motor vehicle tax rates, including reducing the level of vehicle ownership. Meanwhile, the positive impact for the government is the increase in motor vehicle tax rates, namely the increase in local revenue in terms of local taxes, especially motor vehicle taxes. The negative impact was carried out by the community, namely the people who became the masters of the vehicles taking active resistance, namely tax avoidance, with the development of current knowledge it also had an impact on society. By increasing the knowledge and intellectuals of the community so that people are able to think about circumventing the existing rules, the community is able to take advantage of the loopholes of an existing regulation in order to ease the tax burden that must be paid by a taxpayer, this is done so that vehicle owners do not have to pay vehicle taxes at a higher rate.

Implementation of the Progressive Tax Policy for 4Wheeled Motor Vehicles at the Regional Revenue Service of Province $\mathrm{X}$ presents a progressive tax policy with two sides, namely the positive side and the negative side. On the positive side, the public hopes that the government can reduce the rate of growth of motorized vehicles, especially four-wheeled motorized vehicles so as to reduce the level of congestion. Likewise with public transportation, such as improving public transportation, namely city transportation, roads that are continuously repaired to remote areas and driving comfort. People want the convenience of using public transportation so that they feel the impact of the progressive tax policy they have paid. Meanwhile, on the negative side, the public feels a lack of socialization from the government before the progressive tax policy is implemented.

Payment of motor vehicle tax which has become 2 (two) times is very burdensome for the community. Likewise for business actors such as car showrooms. They have felt the impact of this progressive tax policy with the decline in car sales figures in recent months.

The economic, social and political conditions experienced by the government are the increase in local revenue through this progressive tax policy which is based on data processed from the recapitulation of tariff receipts processed from the recapitulation of progressive tariff receipts implemented by 13 (thirteen) Revenue Service Units conveyed contribution of progressive tariff collection to motor vehicle tax revenue is $\mathrm{Rp}$. 36,970,525,665, with a total of 10,600 units. On the other hand, what the public feels is a decrease in income in terms of car sales (showroom) and the fees paid annually are felt to be 2 (two) times which is considered burdensome. The public hopes that there will be improvements in public transportation when this progressive tax starts to be applied, such as proper city transportation, better roads and comfort in driving. On the social side, the government thinks that the public accepts the presence of this progressive tax well, but the facts in the field state that there are many people who complain about this progressive tax policy. In various ways the government has always carried out socialization activities through mass media, television advertisements (TV), social media, banners, stickers about the presence of this progressive tax policy so that the public can understand the purposes and objectives of the collection of progressive tax rates.

However, the people also want an increase in their social standard of living in the eyes of other communities. They want to have more than one 4-wheeled car / motorized vehicle in order to prove that they are a group of people who are (above average), but when the progressive tax policy began to be implemented, they shouted that they would object to paying motorized vehicle tax every year. which becomes 2 (two) times which impact on all means in avoiding this progressive tax. For example, borrowing a neighbor's / relative / family's Identity Card in the name of a second car ownership and so on, which has an impact on the government's difficulty in verifying and database data. This is one way for society to avoid the presence of progressive tax rates that cause public disobedience to the government in paying progressive taxes.

On the political side, there is always political influence in determining public policy (in this case, progressive tax policy). It is impossible to say that policy is not a product of a political process. Policy formulation is not made without certain considerations. Purwanto (2005) states that there are assumptions regarding the formulation of policies, which are not limited to only one actor, often do not start with clear problem formulations, are not monopolized by a government institution, formulations and reformulations can occur continuously. continuous in the long term and is a competition between actors which creates a situation where there are winners and losers. The essence of policy making is the use of authority possessed by the government by allocating various available resources as an effort to carry out the government's role. The realization of the role of government in various aspects of life.

\section{CONCLUSIONS AND SUGGESTIONS}

\section{Conclusion}

Based on the results of research and discussion, it can be concluded that

1. Implementation of Progressive Tax Policy for Motor Vehicles at One-stop Administration Services Office X is running well, it's just that there are several obstacles in implementing the Progressive Tax Policy, namely the 
socialization is not optimal because there are still some people who do not know about progressive tax policies for motor vehicle. Samsat officers have performed services in accordance with the policy's Operating Standards, seen from the results of interviews with taxpayers.

2. Seeing the existing social conditions of the community have not had a positive influence on the implementation of this policy. It can be seen from the public as taxpayers who are still looking for loopholes so as not to be exposed to this progressive tax policy on motorized vehicles. This policy is still not fully supported by the parties.

3. Implementation of the Progressive Tax Policy for 4wheeled Motor Vehicles at the Regional Revenue Service of Province X is quite good. This can be seen from the model of public policy implementation, namely policy standards and policy targets, policy resources, communication between organizations and implementation activities, characteristics of the implementing agency, social, economic and political conditions as well as the attitude of the implementer in understanding high policies associated with Operational Standards. The procedures of the Provincial Regional Revenue Service, namely socialization, improvement of public services, determining the value of taxes and implementing resources in implementing the progressive tax policy of 4 (four) wheeled motorized vehicles in $\mathrm{X}$ City.

\section{Suggestion}

Based on the description of the conclusions above, the

following suggestions can be recommended:

1. The need for socialization to the public, so that people understand and know and build awareness of the importance of paying taxes in an orderly and disciplined manner.

2. In order for employees of policy implementing agencies whose performance is already good, they must be able to be improved again, as well as employees whose performance is not good, their performance must be improved again. The government must improve the structural bureaucracy in order to achieve effective and efficient performance.

Dispenda parties must intensify coordination regarding progressive tax policies on motorized vehicles towards the executive or legislative branches

\section{REFERENCES}

[1] Adiputra, M., Karamoy, H., \& Pangerapan, S. (2018). Evaluation of the Implementation of Progressive Taxes on Motor Vehicles in North Minahasa
Regency, North Sulawesi Province. Going Concern: Journal of Accounting Research, 13 (03).

[2] Ahmad, Jamaluddin. 2015. Public Administration Research Methods Theory and Application. Yogyakarta: Gava Media.

[3] Dwipurna, M. W. F. (2015). Implementation of Motor Vehicle Progressive Tax Policy in Bandar Lampung City (Doctoral Dissertation, Faculty of Social and Political Sciences).

[4] Dwipurna, M. W. F. (2015). Implementation of Motor Vehicle Progressive Tax Policy in Bandar Lampung City (Doctoral Dissertation, Faculty of Social and Political Sciences).

[5] Dwipurna, M.Waya Fahriza. 2015.Implementation of the Progressive Motor Vehicle Tax Policy in the City of Bandar Lampung. University of Lampung: Bandar Lampung. Fajariani. 2012.Analysis of Progressive Tax Rate Imposition on Motor Vehicle Taxpayers Based on "The Four Maxims". State University of Surabaya: Surabaya.

[6] Kuswandi, A. (2019). The Effectiveness of Progressive Tax Policies on Motor Vehicle Taxes by the Regional Revenue Management Center for the City of Bandung Iii Soekarno-Hatta Regional Revenue Agency of West Java Province (Doctoral Dissertation, Fisip Unpas).

[7] Mardiasmo. 2018. Latest Edition of Taxation. CV. Andi Offsest. Yogyakarta.

[8] Nuzul. 2015. Analysis of the Application of Progressive Motor Vehicle Taxes in the Context of Advertising Tax Receipts in the City of Manado. Journal of Accounting Research Going Concern Regional Regulations of North Sulawesi Province. Number 7 of 2011 concerning Local Taxes. Value Added Payable At UD. Leonel. EMBA Journal, Vol.2 No, 2. ISSN: Pontoh, Winston. 2013. Accounting Concepts and Applications. Moeka Publishing page. Jakarta PPH Article 4 Paragraph (2). Going Concern Accounting Research Journal Vol. 12. No. 2.

[9] Pratiwi, F. W. (2016). The Effect of Policy Implementation on the Effectiveness of Motor Vehicle Tax Revenue from Progressive Rates in the Regional Revenue Service Branch of the Bandung City Region Ii Kawaluyaan (Doctoral Dissertation, Library).

[10] Official, Siti. 2014. Taxation Theory and Case 4th Edition. Salemba Empat. Jakarta Sam Ratulangi. Sam Ratulangi. Manado

[11] Sinulingga, L. O. B., Nasution, M. H. T., \& Batubara, B. M. (2018). Implementation of Progressive Tax Policies for Motor Vehicles. Perspectives, 7 (1), 19-23.

[12] Sudrajat, E. I. (2017). Implementation of Motor Vehicle Progressive Tax Policy in West Java (Study in Bandung City, Depok City and Garut Regency) (Doctoral Dissertation).

[13] Sujarweni, V. Wiratna. 2014. Research Methodology. New Library: Yogyakarta.

[14] Suprianto, Edy. 2011. Taxation in Indonesia. Graha Science: Yogyakarta

[15] Supriliyani, N. W., \& Yudharta, I. P. D. (2018). Dynamics of Implementation of Progressive Motor Vehicle Tax Policy in Bali Province Based on Regional Regulation No. 8/2016: (Case Study: Denpasar City). Adhum: Journal of Research and Development in Administrative Sciences and Humanities, 8 (1), 1-14.

[16] Suryabrata., 2013. Research Methodology, PT. Raja Grafindo Persada: Jakarta

[17] Tahir, Arifin. 2015. Public Policy and Transparency of Local Government Administration. Bandung: Alfabeta.

[18] Law of the Republic of Indonesia Number 28 of 2009 concerning Regional Taxes and Regional Levies Regional Regulation X Number 1 of 2011 concerning Regional Taxes of Sam Ratulangi University. Vol. 13. No. 2. Sam Ratulangi University.

\section{AUTHORS}

First Author - Muldjadi Djaja, SE.Ak, SH, CPA, CA, BKP Institut STIAMI, kkpmuljadi@yahoo.com 
